\title{
Natural and historic heritage of the Bochnia salt mine (South Poland)
}

\author{
Janusz WIEWIÓRKA ${ }^{1}$, Krzysztof DUDEK ${ }^{2}$, Józef CHARKOT ${ }^{3}$ \\ Malgorzata GONERA ${ }^{4}$ \\ ${ }^{1}$ Wieliczka and Bochnia Salt Mines, Park Kingi 5, 32-020 Wieliczka, Poland \\ ${ }^{2}$ AGH University of Science and Technology, Faculty of Geology, Geophysics and Environmental Protection, Al. \\ Mickiewicza 30, 30-059 Kraków, Poland \\ ${ }^{3}$ Cracow Saltworks Museum Wieliczka, ul. Zamkowa 8, 32-020 Wieliczka, Poland \\ ${ }^{4}$ Polish Academy of Sciences, Nature Conservation Institute, Al. Mickiewicza 33, 31-120 Kraków, Poland
}

Received March 2009; accepted May 2009

Available online June 2009

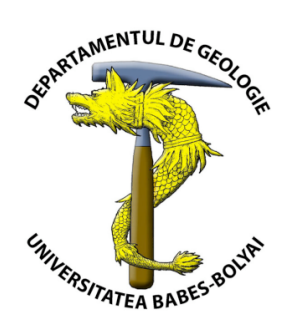

\begin{abstract}
The Bochnia Salt Mine, presented in this paper, is situated ca. $40 \mathrm{~km} \mathrm{E}$ of Cracow, in the southern part of the Neogene Carpathian Foredeep, close to the Carpathian edge. In this region the rock-salt deposits formed as a result of the Late Miocene folding and local tectonic thickening of Badenian evaporites. The Bochnia deposit, situated in the almost vertical N limb of the Bochnia Anticline, stretches ca. $7 \mathrm{~km} \mathrm{WE}$, but only 15-200 m NS. Salt mining in Bochnia began in the thirteenth c. and continued until 1990. The historic part of the mine, since 1995 operated by a company supplying health and tourism services, is an officially listed monument of historic heritage. Legal protection also comprises 27 sites of key value for the geology of the deposit. These documentation sites record the whole profile of the evaporite series and the adjacent beds, main and minor tectonic structures, as well as mineralogical curiosities, such as fibrous halite and enterolithic anhydrite. For some years, efforts have been made to enter the Bochnia Salt Mine, in 2008 visited by over 140000 tourists, on the UNESCO World List of Cultural and Natural Heritage.
\end{abstract}

Key words: Bochnia salt mine, Miocene, protection.

\section{INTRODUCTION}

The historic Salt Mine in Wieliczka, since 1978 on the UNESCO First World List of Cultural and Natural Heritage, is one of the most spectacular tourist attractions in Poland. Situated about $15 \mathrm{~km} \mathrm{SE}$ of Cracow, a historic capital of Poland, the mine is visited annually by over a million tourists. The Bochnia Salt Mine (ca. $40 \mathrm{~km}$ east of Cracow), sometimes called the older sister of Wieliczka, is less known, but by no means less interesting. In both these mines, recently briefly presented by Garlicki (2008), exploitation of rock salt of the Miocene age began in the thirteenth century and continued for over 700 years. The salt deposits of Wieliczka and Bochnia are situated in the southern part of the Carpathian Foredeep, in close proximity to the Flysch Carpathian border (Fig. 1).

\section{GEOLOGY}

In the Wieliczka-Bochnia area the Middle Miocene (Badenian) salt-bearing formation consists of terrigenous, argillaceous and clastic sediments at the bottom (the Skawina Beds), an evaporite series (the Wieliczka Beds), and marly clays, siltstones and sandstones of the Chodenice Beds at the top (Garlicki, 1968, 1979) (Fig. 2). The latter are partly overlaid by undisturbed sands and sandstones of the Grabowiec Beds (Late Badenian). The evaporite Wieliczka Beds consist of a series of intercalating layers of anhydrite, marly clays, clays with dispersed halite crystals (so-called zuber) and with anhydrite, as well as rock salt.

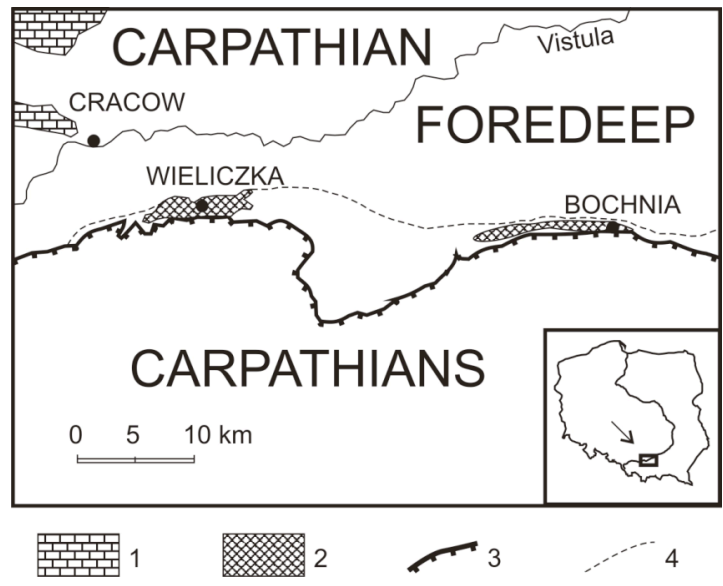

Fig. 1. Geological sketch of the Wieliczka-Bochnia area. 1 - platform Mesozoic sediments; 2 - Bochnia and Wieliczka salt deposits; 3 - Flysch Carpathian border; 4 - extent of folded Miocene sediments. 
This series is interpreted as representing five uncompleted sedimentary cycles (cyclothems), lacking in potassium-magnesium salts (Poborski, 1952; Garlicki, 1968). The total primary thickness of the evaporite series in the vicinity of Bochnia is estimated at ca. 70 metres (Fig. 2). In the Bochnia Salt Mine this sequence was subdivided (Poborski, 1952) into: basal anhydrite, lower zuber, southern salts, marly clays, clays with anhydrite, upper zuber with rock salt blocks, marly clays with anhydrite and intercalations of crystal salt, middle salts, clays with anhydrite, northern salts, clays, and top anhydrite. In some places, just below and within this profile, thin (several millimetre thick) horizons of pyroclastic sediments were recognised, labelled WT-1, WT-2, and WT-3. These horizons, first discovered in the Wieliczka Salt Mine (Wiewiórka, 1979), proved to be very useful for correlating the Wieliczka and Bochnia rock-salt deposits (Bukowski, 1999). Biotite crystals separated from the tuff WT-3 were dated using the K-Ar method to 13.6 Ma (Dudek et al., 2004).

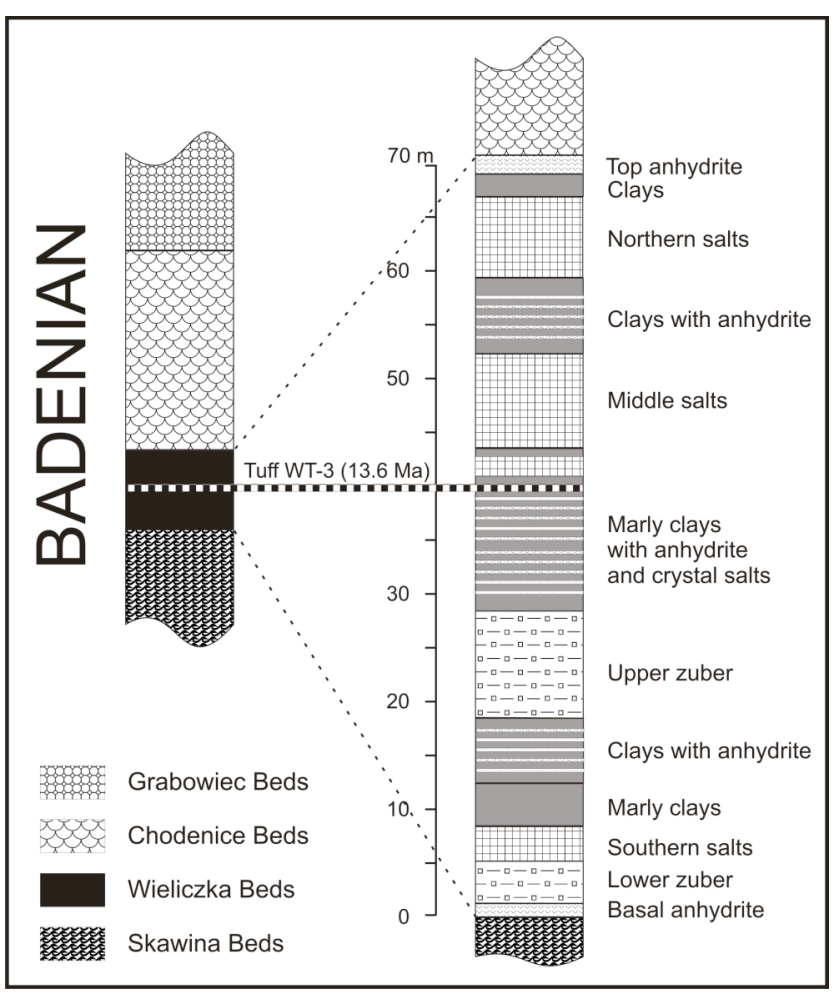

Fig. 2. Lithostratigraphical profiles of the Middle Miocene (Badenian) in the Wieliczka-Bochnia area (left) and the evaporite series (Wieliczka Beds) in the Bochnia Salt Mine (right).

In the Late Miocene the southern parts of the Badenian salt-bearing formation were folded together with the Flysch Carpathians and pushed northwards. Hence, the whole formation is divided into a relatively undisturbed autochthonous unit and an overthrust unit, also called allochthonous or folded Miocene (Fig. 1). Major deformation of the lithologically diversified sequence led to local tectonic reduction and/or thickening of the rock-salt layers, which, in turn, resulted in the formation of rock-salt deposits, including those in Wieliczka and Bochnia. In the vicinity of Bochnia, directly north of the Carpathian edge, the Badenian sediments are folded in two anticlines, relatively narrow and steep, stretching WE, with flysch sediments at their cores (Fig. 3). The latter is proof of the deposition of Badenian sediments in this area above the flysch complex.

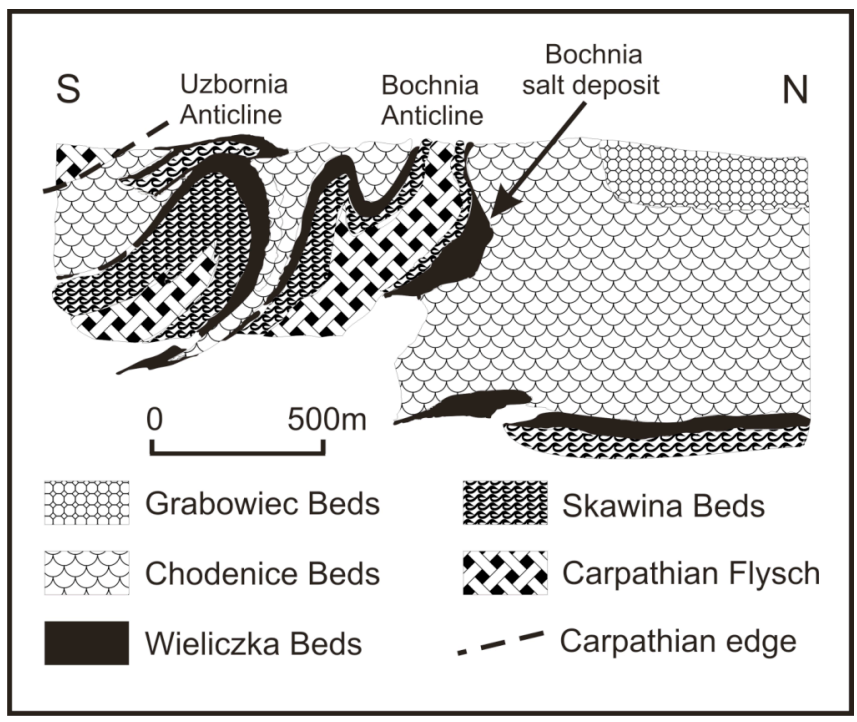

Fig. 3. Geological cross-section through the vicinity of Bochnia (after Garlicki, 1968, simplified).

The Bochnia salt deposit, situated in the almost vertical northern limb of the Bochnia Anticline, stretches WE in a narrow, lens-shaped belt ca. $7 \mathrm{~km}$ in length (Poborski, 1952). It continues westwards to the villages of Siedlec, Moszczenica, and Łężkowice, where salt was exploited using the wet, leaching method in the second half of the twentieth century (until 1991). The Bochnia deposit is largest at a depth of 200-400 metres, where it reaches $200 \mathrm{~m}$ in thickness (NS). Such geometry of the deposit, with almost vertical layers, was at the origin of naming three rock-salt complexes as the southern, middle and northern salts, respectively. They formed due to the tectonic enrichment of the rock-salt layers, which were internally folded within larger-scale overthrust folds. Unlike the plastic salt, the more rigid layers of marly clays and anhydrite are frequently fractured, torn and displaced, the fissures having been filled with secondary anhydrite and fibrous halite. At the surface, where the salt was eroded, a clay-gypsum crust formed, covered with Pleistocene loess, dissected locally by a small river, the Babica, and its tributary streams.

\section{EXPLOITATION}

Archaeological finds and studies point to exploitation of salt-water springs and saltmaking in the vicinities of Wieliczka and Bochnia since the Middle Neolithic period (ca. 3500 BC). As surface brine sources became exhausted, in the Middle Ages (twelfth and thirteenth c.) brine wells were drilled, which eventually facilitated the discovery of the rock salt. In Bochnia this happened in the mid-thirteenth century; the site of the earliest mining is marked by the Sutoris shaft, which is situated in the very heart of the town, and still in use as the main shaft of the mine. Several years later, rock-salt mining began in Wieliczka as well. By the end of the thirteenth century the mines in Wieliczka and Bochnia were united in a royal enterprise, the 'Cracow Saltworks'. In 1368, the customary mining law was codified in the form of the socalled 'Statute' of King Kazimierz the Great. This, combined with Poland's latemediaeval prosperity, triggered the dynamic development of both mines and a rapid increase in salt production. The Cracow Saltworks was the biggest industrial enterprise in Old Poland; in the sixteenth and seventeenth centuries it 
employed up to 2000 workers, nearly 500 of them in Bochnia (Jodłowski et al., 1988).

It should be noted, however, that, due to the more difficult geological and mining conditions, the output of the mine in Bochnia was lower than that in Wieliczka, but the cost of exploitation higher. At the beginning of the sixteenth century, for instance, Bochnia supplied over $40 \%$ of the total Cracow Saltworks output of ca. 16000 tonnes, but by the end of that century this had fallen to ca. $20 \%$ of a total of ca. 32000 tonnes. The oldest shafts (Sutoris, Gazaris, Regis, Floris) reached depths of about 60-70 metres. Greater depths (to $300 \mathrm{~m}$ in the seventeenth c.) were reached by means of a complicated system of inclined galleries, crosscuts, and small underground shafts. In the second half of the sixteenth century the Campi shaft was dug in the western part of the deposit; this shaft, which originally reached ca. 100 metres, is still in use as one of two principal shafts of the mine. Not until the second half of the eighteenth century was some order brought to the hitherto chaotic exploitation with the digging of the first straight, longitudinal gallery, August, $212 \mathrm{~m}$ below the Campi shaft leading eastwards to the Floris shaft (Wojciechowski, 1981). After the first partition of Poland (1772) Cracow Saltworks passed under the Austrian administration, which remained in power until 1918.

The nineteenth and twentieth centuries were marked by mechanisation of mining works, industrial exploitation from increasingly lower levels of the mine (to a depth of $470 \mathrm{~m}$ ), and steady growth in output, e.g. 62,000 tonnes in 1938/39 (Jodłowski et al., 1988). In spite of that, in the 1920s, the exploitation cost was still significantly higher than in both Wieliczka and the newly opened Permian salt mine in Wapno (N Poland). In 1930 the Polish government even decided to close down the mine in Bochnia. Production in the mine, however, did not ultimately cease until 60 years later; in the 1930s its liquidation was hindered by high unemployment at the time of the Great Depression, then the Nazi-German administration (1939-1945) and the communist authorities of the Polish People Republic (19451989) cared much more about the salt production than about the economic aspects of the mining in Bochnia. On the other hand, because extraction continued in the mine until 1990, we were able to broaden substantially our knowledge about the geology of the deposit (see e.g., Poborski, 1952), as well as to preserve the old galleries and chambers for the time when it became obvious that the Bochnia Salt Mine should be protected for its natural and historic heritage.

\section{PROTECTION AND CONSERVATION}

As early as in 1981 the historic parts of the Bochnia Salt Mine, i.e. the six oldest levels, were officially inscribed in the local (Tarnowskie voivodeship) register of historic monuments. Production of rock salt and brine in the Bochnia Salt Mine ended definitively in 1990, and the enterprise went into liquidation. The lowermost levels of the mine (the tenth to sixteenth ones, below a depth of $289 \mathrm{~m}$ ) have been successively backfilled with sand and/or barren rocks. Since 1995 the historic part of the mine has been operated by a company called Bochnia Salt Mine Health Resort Ltd., which supplies health and tourism services. The company offers guided tours of the mine, daily and overnight underground stays in its 'therapeutic microclimate', as well as various social events. Visitors enter the mine through the historic Sutoris shaft (Fig. 4a), renovated and adapted to its new functions in 1993-1995. In the neighbouring buildings, former property of the mine, the company operates the Centre of Rehabilitation and Biological Regeneration (with inhalations and brine baths), the Sutoris Hotel, the Grota Restaurant, and the Szuflada Cafe.

On 26th September 2000, the President of the Republic of Poland signed a decree officially recognising 'the Salt Mine stretching beneath the town of Bochnia' as a monument of historic heritage. Legal protection encompasses ca. $60 \mathrm{~km}$ of mining galleries and chambers situated on nine exploitation levels, at depths from 70 to 289 metres. The protected area stretches $3.5 \mathrm{~km}$ along the WE axis, but a maximum of $250 \mathrm{~m}$ in the NS direction, exactly the width of the deposit. In spite of legal protection, however, direct access to outcrops in the mine is considerably restricted in comparison to when salt was still being exploited, when the galleries and chambers exhibited all units of the profile, main and minor tectonic structures, and minerals formed in secondary processes. At present, the deepest parts of the deposit have become inaccessible for ever, and access to many of the preserved and protected sites is difficult for security reasons. Moreover, large parts of the tourist route are protected with wooden linings, which shut out the outcrops. In order to preserve the mine's natural heritage, 27 accessible sites of key value in terms of the geology of the deposit have been documented with photographs, sketchmaps, profiles, and exhaustive descriptions. Since 5th December 2005 they have been under legal protection pursuant to a decree by the Małopolska voivode establishing 27 documentation sites for the geology of the Bochnia salt deposit.

Twelve of them are situated on the tourist route, whereas access to the remaining fifteen requires a special itinerary. The site on the first level (Danielowiec, $70 \mathrm{~m}$ below the surface) exhibits strongly folded northern salts and clays with anhydrite, densely cut by fissures filled with fibrous salt and gypsum. One of the sites on the second level (Sobieski) reveals the Chodenice Beds and the upper part of the evaporite series with the top anhydrite, as well as secondary halite in the form of stalactites, salt covers and fibrous crystals, known as 'St. Kinga's hair'. Three sites on the third level (Wernier, a depth of $138 \mathrm{~m}$ ) document all three salt complexes, the continuous profile from the marly clays of the Skawina Beds to the northern salts, and ubiquitous carbonised vestiges of Miocene plants. Five documentation sites were established on the fourth level, August (178 m below the Sutoris shaft), the main axis of the tourist route. One of them includes the St. Kinga Chapel (Fig. 4b), built in 1746 and successively enlarged to its present dimensions: $31 \mathrm{~m}$ in length, $21 \mathrm{~m}$ in width, and 5-6 $\mathrm{m}$ in height. The ceiling and walls of the chapel display various salt-tectonics structures, stressed by distinct relief of the clays with anhydrite - an effect of salt dissolution in the humid air. In the next site, nearby, one may observe the northern salt complex, of varying thickness, with folds and minor deformations. The walls of the perpendicular August gallery show the profile with the southern border of the deposit; from the Carpathian flysch and Skawina Beds to the middle salts. There are also traces of early, fifteenth-century exploitation; a small gallery once backfilled with barren rocks and horse manure, and re-exploited in the seventeenth century (Wiewiórka et al., 2007). 

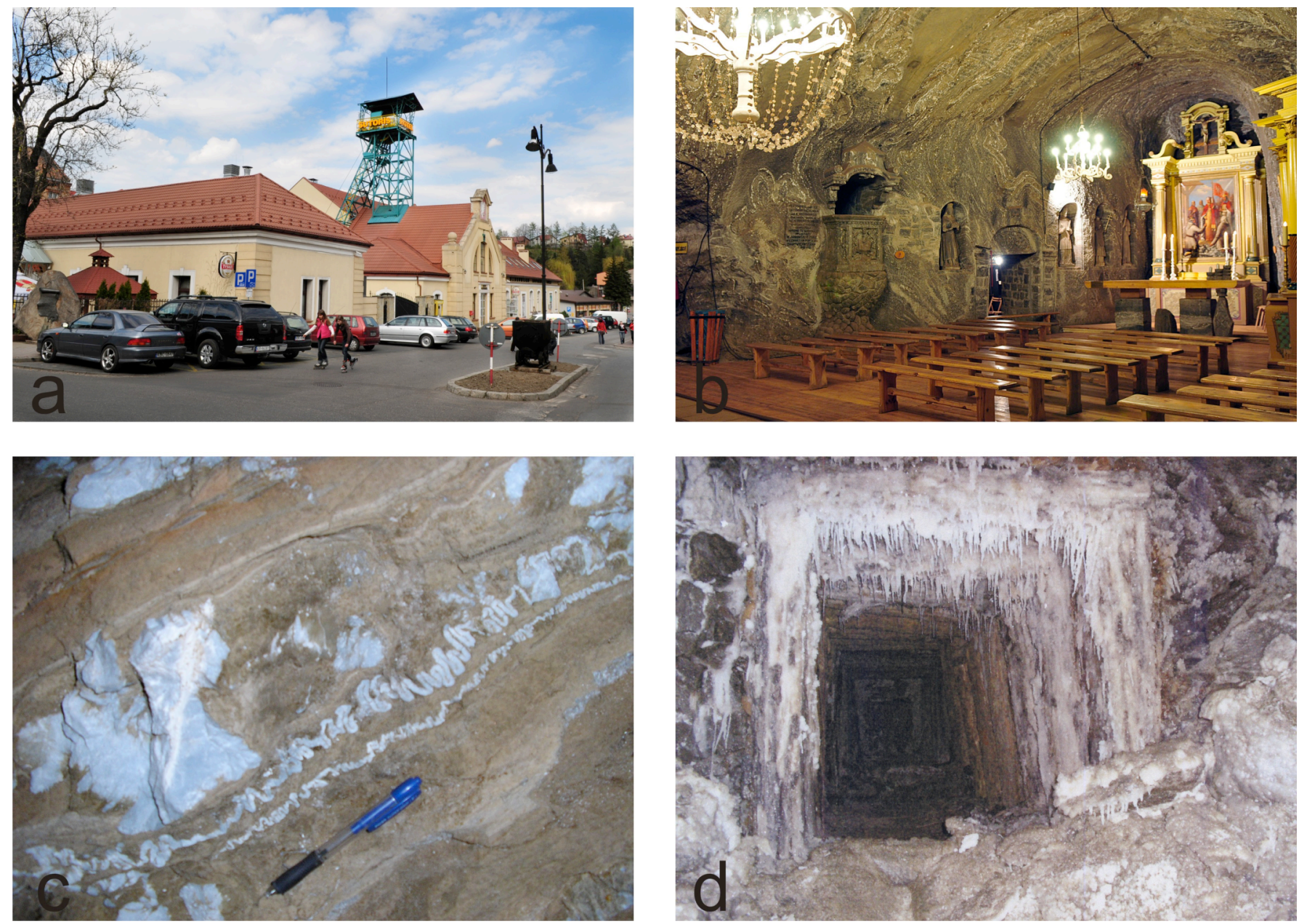

Fig. $4 \boldsymbol{a}$. The Sutoris shaft in the centre of Bochnia; $\boldsymbol{b}$. St. Kinga's Chapel; $\boldsymbol{c}$. enterolithic anhydrite in marly clay in the perpendicular August gallery; d. secondary halite stalactites on the fifth level (Lobkowicz) of the Bochnia Salt Mine.

Fifteen sites beyond the tourist route, on lower levels of the mine, document among others: the tuff level WT-3 (dated to $13.6 \mathrm{Ma}$ ) just below the crystal salt and the middle salts complex, minor-scale synclines and anticlines of salt complexes, the slight but consistent westward deepening of the major fold axes, exotic blocks of the Carpathian flysch in the anhydrite clay and zuber, the upper part of the profile with northern salts, the top anhydrite and the Chodenice Beds, and tectonic contact between the northern and tectonically reduced middle salts. At numerous of the documentation sites one can observe mineralogical curiosities, such as enterolithic anhydrite (Fig. 4c), crystal halite in zuber, as well as recently formed secondary halite in the form of cauliflowers, stalactites (Fig. 4d), crusts, skeletal or fibrous crystals, secondary anhydrite and gypsum. The established documentation sites record the whole profile of the evaporite series together with the accessible outcrops of the adjacent beds. Correlation is aided by mineralogical analysis and dating of tuff levels (Dudek et al., 2004) and microfauna analysis of foraminifers from marly parts of the profile (Gonera, 2001). It should also be noted, that the mine is continuously subjected to recent tectonic movements, in particular, to the pressure exerted by the Carpathians (Toboła and Bezkorowajny, 2006). This results in the relatively rapid compression of high and narrow chambers, sometimes called 'underground cathedrals'.

\section{CONCLUDING REMARKS}

In 2008 the mine was visited by over 140000 tourists, including several hundred geology students and geologists. For several decades the Bochnia Salt Mine has been a superb educational site for mining and geology students. Presently, the key issue consists in protecting and preserving for future generations as much as possible of the Earth history pages written in the dark chambers and galleries of the mine. For some years, efforts have been made to enter the Bochnia Salt Mine on the UNESCO World List of Cultural and Natural Heritage.

Acknowledgement. Part of the study was supported by the AGH-UST WGGiOS grant no 11.11.140.158.

\section{R E F E R E N C E S}

Bukowski, K. 1999, Comparison of the Badenian saliferous series from Wieliczka and Bochnia in the light of new data. Prace Państwowego Instytutu Geologicznego, 58: 43-56 (in Polish, English summary).

Dudek, K., Bukowski, K. \& Wiewiórka, J. 2004, Radiometric dating of Badenian pyroclastic sediments from the Wieliczka-Bochnia area. In $8^{\text {th }}$ Polish Scientific Session - Dating of Minerals and Rocks, p. 19-26 (in Polish, English summary). 
Garlicki, A. 1968, Autochthonous salt series in the Miocene of the Carpathian Foredeep, between Skawina and Tarnów. Biuletyn Instytutu Geologicznego, 215: 5-78 (in Polish, English summary).

Garlicki, A. 1979, Sedimentation of Miocene salts in Poland. Prace Geologiczne PAN, 119: 1-67 (in Polish, English summary).

Garlicki, A. 2008, Salt Mines at Bochnia and Wieliczka, Przeglad Geologiczny, 56 (8/1): 663-669.

Gonera, M. 2001, Foraminifers and palaeoenvironment of the Badenian (Middle Miocene) Formation in the area of the Upper Silesia. Studia Naturae, 48: 5-211 (in Polish, English summary).

Jodłowski, A., Wiewiórka, J., Piotrowicz, J., Keckowa, A., Dziwik, K. \& Wyrozumski, J. 1988, The history of Kraków Salt-Works. Wieliczka, 460 p. (in Polish, English summary).

Poborski, J. 1952, The Bochnia salt deposit on the geological background of region. Biuletyn Państwowego Instytutu Geologicznego, 78: 3-160 (in Polish, English summary).
Wiewiórka, J. 1979, Przewodnie poziomy tufitowe w kopalni soli Wieliczka. Sprawozdania z Posiedzeń Komisji Naukowych PAN, Oddziat w Krakowie, 21 (1): 176-178 (in Polish).

Wiewiórka, J., Charkot J., Dudek K. \& Gonera M. 2007, New data on the salt-deposit geology and the mining history in the Bochnia Salt Mine. Gospodarka Surowcami Mineralnymi, 23, special volume 1: 157-162 (in Polish, English summary).

Wojciechowski, T. 1981, Outline of spatial development of the Bochnia Salt Mine until 1772. Studia i Materiaty do Dziejów Żup Solnych w Polsce, 10: 45-101 (in Polish, English summary).

Toboła, T., Bezkorowajny, A. 2006, Neotectonic and recent movements revealed in the Bochnia Salt Mine. Geologia, 32 (1): 5-19 (in Polish, English summary). 